\title{
KIR2DL2 Gene
}

National Cancer Institute

\section{Source}

National Cancer Institute. KIR2DL2 Gene. NCI Thesaurus. Code C129036.

This gene plays a role in the negative regulation of natural killer cell activity. 